\title{
PICTURE BOOKS IN EFL; vehicles of visual and verbal literacy
}

\author{
Anna Birketveit ${ }^{\mathrm{a}}$ \\ a University College of Bergen
}

\begin{abstract}
:
Drawing on recent developments within the teaching of foreign languages, this article discusses the potential of picture books in teaching visual and verbal reading skills in English as a foreign language (EFL). Learner motivation is considered to be of increasing importance, and the article discusses various aspects of picture books which can contribute to learner motivation for reading. Through a thorough examination or the iconotext and peritext of three picture books, this article discusses how the interaction of pictures and words work together to bring across messages. In The Stinky Cheese Man and Other Fairly Stupid Tales by Jon Scieszka and Lane Smith traditional fairy tales are subverted and interrogated. In Rose Blanche by Ian McEvan and Roberto Innocenti, a child's experience of the Second World War is explored, and in Zoo by Anthony Browne, the text addresses both the child and the adult reader on the serious themes of human nature and animals held in captivity. Additionally, the pedagogical potential of each text is discussed.
\end{abstract}

\section{Introduction}

Despite the fact that picture books offer new and exciting reading for all competence levels, picture books seem to be a largely undiscovered treasure trove in English as a foreign language (EFL) today. As picture books have at least one picture on every double spread, these texts come with ample visual support that will enable learners of English to cope with more advanced texts than they usually would. By reading picture books, they are exposed to authentic stories and authentic English offering a wider vocabulary than course books or graded readers do.

Another highly important benefit of introducing EFL learners to picture books is that they help develop visual literacy. The term literacy traditionally refers to the ability to read and write verbal text, yet, due to the massive exposure to visual stimuli in today's society, literacy 
has also come to include the ability to read images. Seeing is not just passive reception of stimuli but an active process of meaning making (Rimmereide, 2013:134). Most children and young adults today read and produce multilayered texts in their spare time, for example on social media. Picture books, ranging from very simple to quite complex stories and catering for different reader preferences and reading skills, are ideal texts for training the new literacy.

The Norwegian national curriculum, LK06, includes competence aims pertaining to visual literacy as well as ability to read and understand different types of texts and use different reading strategies. Visual literacy is inherent in the competence aims after year 2, requiring that the learners shall be able to "participate in and experience children's culture from English-speaking countries through words, pictures, music and movement" and after year 7 stating that they shall be able to " express own reactions to English literary texts, films, internet culture, pictures and music". The ability to use reading and writing strategies is required both after year 4 and after year 10. The ability to read and understand different types of texts is a central aim in LK06. Thus after year 7, the pupils shall be able to "read and understand different types of texts of varying length from different sources"and " read children's and youth literature in English and converse about persons and content", and after year 10, they shall be able to "read, understand and evaluate different types of texts of varying length about different topics". The icon texts of picture books enable learners to read for detail as well as extensively and meet these important goals in LK06.

Traditionally, picture books have been conceived of as books for the very young, yet this is no longer so. Today, picture books exist for all ages, and they are an art form that challenges readers on all competence levels. Some of them, such as for example Anthony Browne's picture books, are for dual audiences. Barbara Wall (1991) established this term to refer to books that are written for both children and adults. The children will understand the texts at their level whereas the alert adult reader will perceive a deeper meaning to the stories. Readers who are interested in modern visual art forms are likely to find picture books particularly appealing.

As discussed by Birketveit (2013), there are also a number of other reasons why they are excellent material for the English as a Foreign Language (EFL) classroom. Firstly, due to the pictures assisting the reader in the decoding of the story, they give the reader access to authentic language that is often more complex than course book texts. Schmitt (2010:32) claims that the reader needs to understand $98-99 \%$ of the words to be motivated to continue reading a story. However, in a picture book the verbal text and the pictures are equally important in conveying the meaning of the story. Picture books provide an exciting offer of reader involvement, and the picture-text interaction provides endless possibilities for interpretation. Secondly, picture books are ideal texts for EFL because they have short texts. Generally, they are 32 pages long. Thus, they offer the reader the pleasure of reading whole stories instead of extracts of stories much used in course books. There is something deeply satisfying about having read a whole book, and it is likely to give children a sense of accomplishment. According to Penne (2010), the reading process is carried forward by the narrative desire where the reader anticipates and seeks a resolution to the story. Since picture books also come with texts for different competence levels and tastes, they are likely to 
appeal to inexperienced readers who find long texts daunting. They can be a gateway to extensive reading as well as bridging the gap into longer canonical texts. Thirdly, learners like using picture books because they are often witty and amusing and defy reader expectations. Moreover, the pictures exaggerate and enhance the verbal text. Anthony Browne's Zoo discussed later in this article, is an example of this. For all these reasons, there is a need to revise the EFL curricula in teacher training at colleges and universities to include more texts which draw on visual modes of representation.

\section{Theoretical background}

\section{Visual literacy}

Picture books rely on two modes of representation, the visual and the verbal. These modes can interact in many ways in telling the stories offering multiple possibilities of interpretation. While decoding the text, the reader moves back and forth between images and verbal text. Some readers rely mostly on the images whereas others may have their main focus on the verbal text. Both images and verbal text may have "gaps" (Iser, 1974) the reader needs to fill through a careful examination of the two modes of representation. As previously discussed, picture books are often amusing, and the humor is often brought about by a rather neutral verbal text accompanied by pictures that exaggerate and thus add to the meaning of the text. According to Moss, using Ancient Rome by Dorling Kindersley as an example, the doublespread is the starting point for meaning making and the reader has "the freedom to roam the text" (2003: 83), Multimodal texts thus allow for play as opposed to work in the classroom. Different from a verbal text where reading takes place from left to right, top to bottom, in multimodal texts guide the reader's attention to the "salient" features of the text (Moss, 2003:81). Reading images means spatial reading, and picture books help develop visual literacy.

\footnotetext{
[Non linear] composition sets up particular herarchies of the movement of the hypothetical reader within and across the different elements. [In these texts] reading paths begin with the most salient element, from there move to the next most salient element, and so on. Their trajectories are not necessarily similar to that of the densely printed page, left-right and top-bottom, but may move in a circle....from the most salient element...to the text, and from the text back....again, in a circular fashion. Whether the reader only "reads" the (image) and the headline, or also part or all of the verbal text, a complementary, a to-and-fro between text and image, is guaranteed.
}

(Kress and van Leeuwen, 1996: 218-219)

The hermeneutic circle, stating that we understand parts in terms of the whole and the whole in terms of the different parts and where each new reading adds another layer of understanding to the text, can be applied to reading a picture book. In the reading process, the reader's focus will alternate between the details and the whole double-spreads and back and forth between images and texts. 
Nikolajeva and Scott (2006:1) use semiotic terminology to discuss the unique quality of the Picture book. In a Picture book there are two types of signs: the iconic and the conventional. "Iconic, or representational, signs are those in which the signifier and the signified are related by common qualities; that is where the sign is a direct representation of its signified...Conventional signs have no direct relationship with the object signified". To be able to access the meaning of conventional signs, the reader needs to know the code, embodied in the language and the cultural context. According to Nikolajeva and Scott (2006:1), the primary function of the pictures is to describe whereas the primary function of the verbal text is to narrate. Images are superior in describing settings and characters whereas words are best at conveying relationships and emotions. Space is best conveyed by pictures whereas temporal aspects are best conveyed by words.

\section{Iconotext}

In a Picture book, pictures and verbal text are equally important in conveying meaning. A Picture book is defined as ...

text, illustrations, total design; an item of manufacture and a commercial product; a social, cultural, historical document; and foremost an experience for a child. As an art form it hinges on the interdependence of pictures and words, on the simultaneous display of two facing pages, and on the drama of the turning page.

(Bader 1976:1)

The various ways in which pictures and verbal text can interact in a picture book have been an object of study for scholars. Barthes' (1977) distinguishes between anchorage and relay. Images can have multiple meanings and interpretations, and anchorage occurs when the text is used to support one of these meanings. Relay occurs when the text adds meaning, and both text and image work together to elicit meaning.

Nikolajeva and Scott (2006) discuss various types of picture-text interaction in How Picture books Work. When the pictures and the verbal text more or less tell the same story and no meaning is added through one or the other of the two, the relationship is symmetrical. Books for toddlers (type peek-a book) are often symmetrical. When the interaction is complementary, picture and text fill each other's gaps so little is left to the reader's imagination. An example of complementary interaction can be found in the Picture book Rose Blanche discussed below. Figure 9 showing spring triumphing at the spot where Rose was shot and where the concentration camp used to be can serve as an example. The verbal text reads "Rose Blanche's mother never found her little girl. As the week went by another, gentler invasion began." Only through the verbal text do we learn that Rose was killed since she was never found. Only through the illustration do we understand that this is the same spot she died on. Thus, there are gaps in both modes filled by each other without changing the story.

However, with the development of the modern Picture book, new and exciting types of interaction occurred. The word - picture interaction was now characterized by enhancement 
and even counterpoint. Usually, it is the pictures that expand the meaning of the text, but occasionally it can be the other way around. The interaction is enhancing when picture and verbal text are together more than the sum of the two. Zoo by Anthony Browne discussed below is a clear example of enhancing interaction. The interaction is counterpointing when picture and text tell quite diverging stories. Pat Hutchins's Rosie's Walk, which came out in 1968 , is commonly considered the beginning of the modern Picture book in the UK as this book is the first to explore and truly make use of the interaction of pictures and text to tell the story. In fact, the two modes contradict or counterpoint each other (Nikolajeva and Scott, 2006: 17). The verbal text tells the story of a hen going pleasantly about the farm and coming back in time for dinner. When looking at the pictures, however, the true story shows that the hen is in mortal danger of a fox who lays in pray on every double-spread. Fortunately for the ignorant hen, various farm accidents happen to the fox which save the hen. A Picture book often employs a combination of these types of picture-text interaction.

Often intertextuality is a feature of picture books. The term was originally coined by Julia Kristeva in 1966 and refers to hints and allusions to other verbal or visual texts in a given text. The text's meaning is thus shaped by other texts referred to. In a Picture book for example, there may be references to well know fairy tales such as we can find in some of Anthony Browne's books.

\section{Paratext}

The term paratext was coined by Genette(1997) and refers to the epitext (everything that has been said or written about the text or the author or spin off products such as film and various commercial gadgets) and peritext which is the threshold to the story including cover, endpapers, title page, prefaces, types of paper, fonts, layout, illustrations. According to Nikolajeva, the front cover can be considered "the door into the narrative"(2006:109). The endpapers in picture books are often of significance to the narrative so one can say that the narrative starts with the endpapers before the actual beginning of the story. According to Sipe and McGuire, they can be said to function much like a theatre curtain before and after a play, and "plain colored endpapers are often used to indicate the overall mood or tone of the story to follow" (2006: 299). The title page in picture books often has a picture of particular importance to the story and thus creates reader expectations. It also matters what kind of paper is used in the book, for example whether it is glossy or plain. Moreover, varying sizes or boldness of fonts carry meaning as do layout and types or colour of illustrations. They all contribute to the expectations and subsequent meaning-making of the story. In the following, meaning making through a close examination of three picture books will be discussed. The focus will be on analyzing the icon texts and the peritexts of the stories. Additionally, the pedagogical potential of each text will be discussed.

\section{Language learning}

The positive effect of extensive reading on foreign or second language learning has been documented in many studies (e.g. Al-Homoud \& Schmitt 2009; Bell, 2001; Cho \& Krashen, 1994; Elley, 1991; Hafiz \& Tudor, 1989; Hitosugi \& Day, 2004; Pilgreen \& Krashen, 1993; Robb \& Susser, 1989). There are also studies on children's reading of picture books in L1 (Arizipe, E. and M. Styles. 2003). However, there appears to be very little research conducted 
on using picture books as reading material in EFL. A study by Birketveit and Rimmereide (2013) in The Language Learning Journal shows the impact of extensive reading of picture books and illustrated books on Norwegian 11- year old learners' motivation and writing skills. The study shows that the learners were able to write longer and more sophisticated narratives and used more adverbials after a five-week extensive reading project. Children's understanding of the peritext in EFL has been investigated by Sandie Mourao (2013). Through repeated read-alouds of three picture books, the children were exposed to English. They were allowed to share their responses to the peritext in their L1. In her study, she concludes that the children expanded their L2 language and enhanced their cognitive and aesthetic development.

Reading high-interest stories and texts is a pleasurable way of increasing learner motivation and learning language in a meaningful context. Instead of focusing on language in isolation, the target language becomes the medium in which content knowledge and cultural understanding can be learned. In the introduction to Children's Literature in Second Language Education, Janice Bland states that "[t]he English language as the object and sole focus of study is gradually diminishing, and content-based EFL classrooms are becoming the norm in many types of school" (2013:1). Children's literature provides an excellent vehicle for this aspect of EFL as literary texts offer holistic learning as well as teaching language in context. Bland emphasises the importance of EFL courses for young learners containing children's literature and not just having a focus on communicative learning. It will also help to bridge the gap into adult canonical literature (2013: 3). According to Meltzer (2013:6), it should be a central aim to teach literary literacy, which means to "connect reading to our students' lives and worlds and make them lifelong readers in their mother tongue as well as in L2".

\section{Discussion of texts}

The Stinky Cheese Man and Other Fairly Stupid Tales by Jon Scieszka and Lane Smith.

This is a postmodern and metafictive Picture book written by Jon Scieszka and Lane Smith. It was awarded the Caldecott Honor in 1993. According to Sylvia Pantaleo, "the self-conscious nature of the stories and book design not only draw readers' attention to the metafictive character of the book but also the reading process" (2007: 290). The "playfulness" of the book invites the reader into co-construction of meaning and challenges the reader in the gap-filling process as outlined by Iser, (1978).

Through its subversion of well-known children's tales, it interrogates these stories. The enjoyment of the book depends on familiarity with the original stories, and as such the book also explores the concept of intertextuality. Moreover, the book deliberately draws attention to and plays with the picture book conventions (end-papers, title page, table of content etc.) incorporating them in the overall story. 
The Stinky Cheese Man in one of the stories and part of the book title refers to a subverted version of the Gingerbread Man. Like the former, he jumps out of the oven and runs away, but the old couple do not want to try to catch him because he stinks. Neither do the cow or the two children he meets. When the sly fox ferries him across the river, the "funky" smell makes the fox sneeze so that the stinky cheese man flies off his back and into the river. The fonts of the story mirror the content. Thus, where the little old woman opens the oven to see if he is done, and the stinky smell oozes out, the fonts fall off the lines making waves. As we approach the climax of the story, the fonts are getting bigger, culminating in the very large fonts at the end where the Cheese Man perishes.

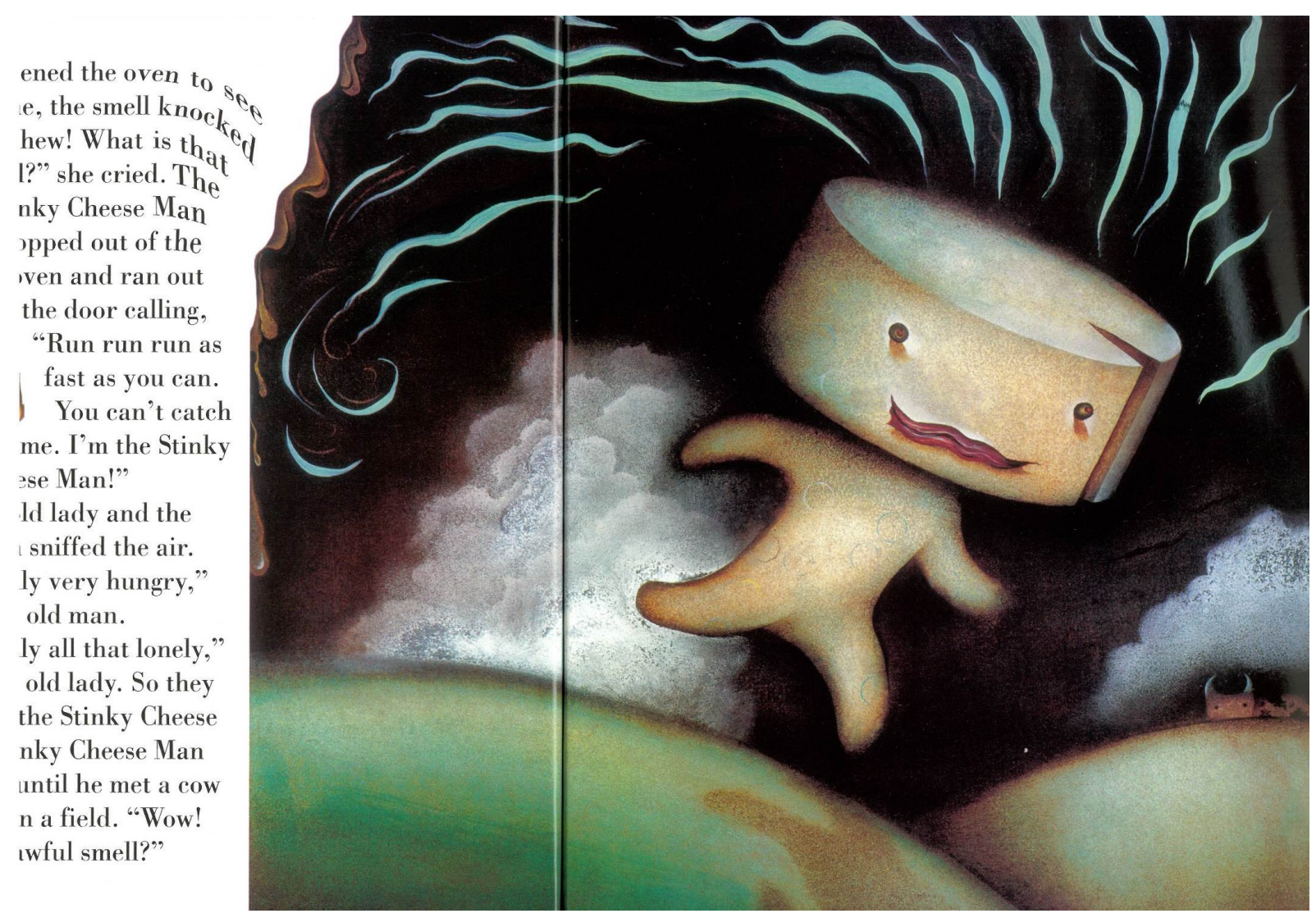

Figure 1: The Stinky Cheese Man and Other Fairly Stupid Tale by Jon Scieszka and Lane Smith.

The book includes other subverted versions of well-known tales, for example Chicken Licken, The Really Ugly Duckling, The Tortoise and the Hair (homophone with Hare), Cinderumpelstiltskin (Rumpelstiltskin), Little Red Running Shorts, Jack's Bean Problem. The Little Red Hen and Jack, the narrator, (also a subversion of Jack in "Jack and the Beenstalk") 
occur and interfere with the stories throughout the book. On the back cover, the Little Red Hen interrogates picture book conventions by asking what this "ISBN guy" is doing there and who will buy this book with "over fifty pages of nonsense". The Little Red Hen appears before the title page asking who will help her plant the wheat, but she is told off by Jack the narrator because she comes too early in the book. Opposite is the title page stating so in big, bold letters with the book's title in parenthesis.

"I have found a kernel of wheat," said the Little Red Hen."Now who will help me plant this wheat? Where is that lazy dog? Where is that lazy cat? Where is that lazy mouse?"

"Wait a minute. Hold everything. You can't tell your story right here. This is the endpaper. The book hasn't even started yet."

"Who are you? Will you help me plant the wheat?"

"I'm Jack. I'm the narrator. And no, I can't help you plant the wheat. I'm a very busy guy trying to put a book together. Now why don't you just disappear for a few pages. I'll call when I need you.'

"But who will help me tell my story? Who will help me draw a picture of the wheat? Who will help me spell "the wheat"?" "Listen Henforget the wheat. Here comes the Title Page!"

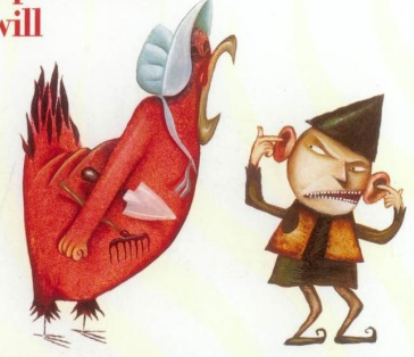

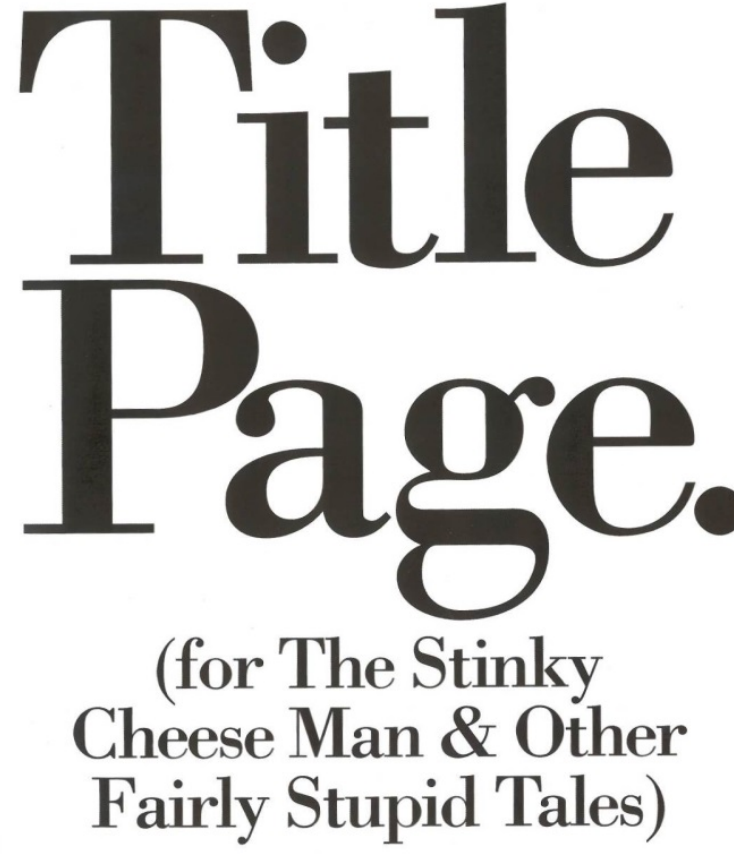

PUFFIN BOOKS

Figure 2: The Stinky Cheese Man and Other Fairly Stupid Tale by Jon Scieszka and Lane Smith.

The following page is the dedication page, but upside-down about which Jack the narrator says he did it deliberately because "Who ever looks at that dedication stuff anyhow?" The following story, "Chicken Licken", is interrupted by Jack, the narrator, who claims he has forgotten the table of contents. Instead of the sky falling, it is the table of contents that falls and squashes everybody. 


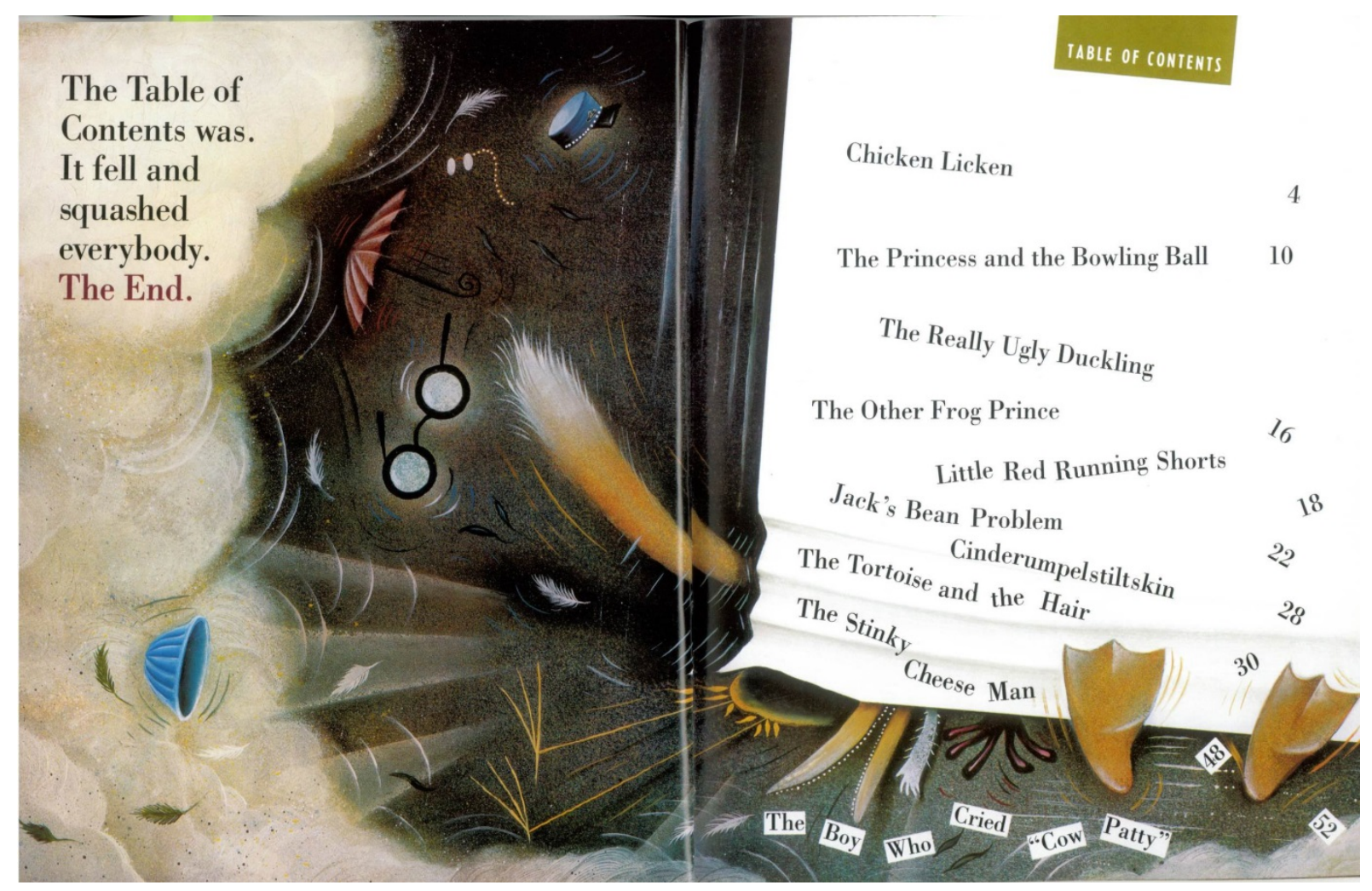

Figure 3: The Stinky Cheese Man and Other Fairly Stupid Tale by Jon Scieszka and Lane Smith.

The end papers of the book are composed of blue and yellow waves, alluding to stink waves, and a few pages before the end of the book, one of the endpapers is inserted which Jack, the Narrator says is a device to lure the Giant in "Jack's Been Problem "to think the book is over so he won't kill Jack. The Red Hen appears again after that bragging about everything she has done and asking who will help her eat the bread. This awakens the Giant "BREAD?" said the Giant. "EAT?" said the Giant and the next illustrations show the Giant spitting out a hen's feather and the hen's bonnet falling to the ground. The very last page simply says "The End." in big, bold letters with Jack, the Narrator, escaping with a big grin on his face. 

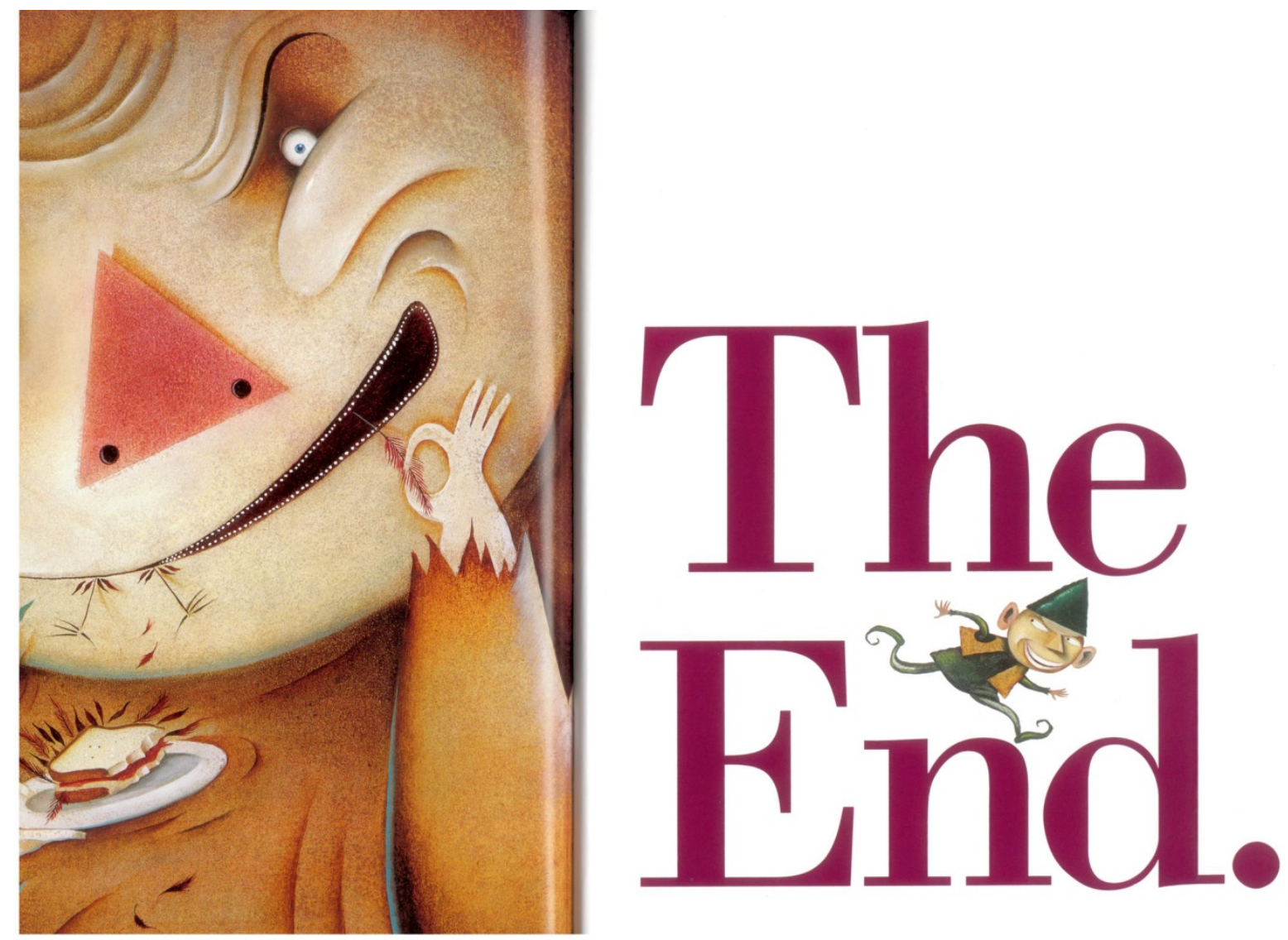

Figure 4: The Stinky Cheese Man and Other Fairly Stupid Tale by Jon Scieszka and Lane Smith.

I would suggest that this book can be used with 12 year-old learners and onwards. The language itself is not very difficult mostly being extracts of well-known fairy tales, but understanding and appreciation of the stories require that the reader understands irony. The book may even appeal to 10th graders. When learners may feel that they are too mature for traditional tales, subversions poking fun at established patterns and conventions can be just that spark of motivation they need. In particular, there are two types of follow-up activities the book seems ideal for. First of all, picture books are creative and exciting types of texts learners should be able to read and analyse. This book lends itself very well to a discussion of Picture book conventions. Only through being familiar with these conventions, back cover, end-papers, dedication page, title page and table of contents etc. can one appreciate the humor of the book. Through teaching the learners about these conventions and then by asking them to investigate how these rules are broken, the aforementioned "playfulness" of the book can be explored.

Secondly, the concept of intertextuality can be explored through this text. The learners can be asked to identify and recap the traditional fairy tales referred to, and then look at how these tales are parodied in the book. Follow-up activities can be fairy tale salad which is in fact what this book already is and as the illustrations being the colours of oil and vinegar indicate (Beckett, 2002:277). In a fairy tale salad, certain well know characters of fairy tales are given 
prominence, in this case Jack the narrator, the Giant, and the Little Red Hen. Then certain other fragments of tales are thrown in, to create a new story. The teacher can present the learners with some well-known fairy tale characters and ask them to create a story with these characters in. Remind the learners that a fairy tale has a beginning, a conflict of some kind and a solution. The teacher can also ask the learners to choose one of the fairy tales in the book and write a different ending to the original tale. Other ideas can be that a group of learners are responsible for writing a different beginning to a well known fairy tale; another group will be responsible for the complication and a third group for the solution or the ending. The fairy tale pattern is a fundamental pattern for storytelling, and therefore deviation from the norm is easy and often calls for laughter.

Rose Blanche by Ian McEwan and Robert Innocenti.

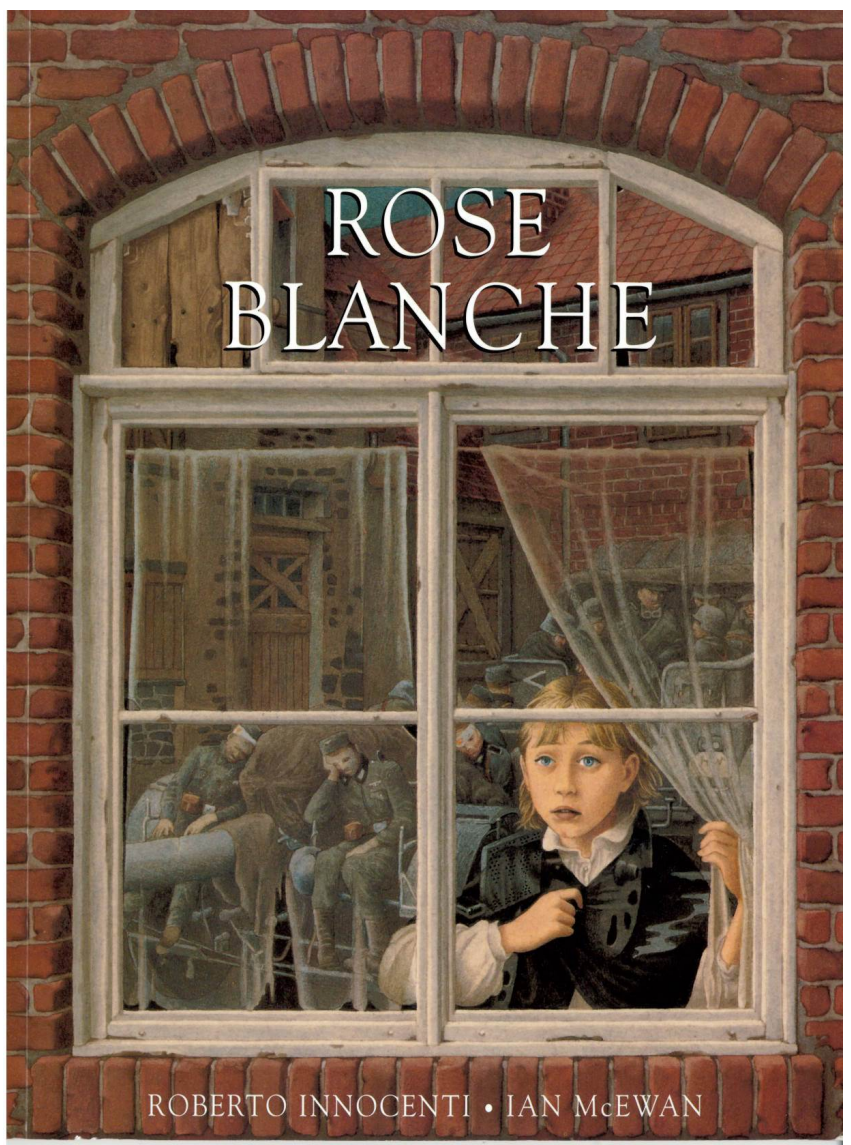

Figure 5: Rose Blanche by Ian McEwan and Robert Innocenti.

This book has been chosen most of all for its visual strength in portraying a child's experience of war. On the back cover of McEwan's adaptation of the story, the quotation of Innocenti reads: "In this book I wanted to illustrate how a child experiences war without really 
understanding it...I was a child when the war passed in front of my door...My father did not want to answer my questions, but I knew that something terrible was happening".

The story originated in Italian with Roberto Innocenti's illustrations and ideas for a story which the Frenchman, Christophe Gallaz verbalized. According to Susan Stan, "the original French text is spare and underscores the allegorical nature of the illustrations" (2004: 24). It is indeed true that the powerfulness of the story is not least due to the illustrations. They are outstanding, brimming with realistic details of Nazi Germany at the same time as they portray suffering and Rose's compassion in subtle ways. This book illustrates very well how pictures, when used skillfully, are unique in describing settings and space. By looking at the illustrations, the reader learns a lot about Nazi Germany. It would take a lot of pages in a verbal text to portray something similar.

The story has been translated and adapted into several languages. There are two versions in English: an American version that is very close to the original and the British version which is Ian McEwan's adaptation of the original. In the original text, the narrator's voice alternates between Rose's $1^{\text {st }}$ person perspective on the first pages and $3^{\text {rd }}$ person omniscient perspective later. In the British adaptation however, the $1^{\text {st }}$ person perspective is gone. One of the effects of this is perhaps to distance and protect the reader from too strong emotional involvement in the story.

The name Rose Blanche is taken from the resistance movement in Nazi Germany, Die Weisse Rose, underscoring Rose's symbolic function. The setting is Nazi Germany in the final year of the Second World War. It tells the story of Rose Blanche who lives with her mother and observes the things happening in her little town. In the beginning of the story, we see Rose together with her mother and the townspeople cheering and waving to the soldiers who are off to fight in the war. On the following pages, we learn that there is food shortage, and that Rose goes shopping for her mother. Despite the difficult situation, there is still normality as Rose goes to school every day, does homework and plays with her friends. Then, one day, a lorry passing through the village breaks down, and a little boy escapes from it running straight into the arms of the town's fat mayor. The soldiers shout at the little boy who starts crying. Rose always observing, discovers more children with pale faces packed into the lorry. Rose is "furious" and knowing all the shortcuts through the town and the forest, she is able to follow the lorry to the concentration camp where she discovers "dozens of silent, motionless children staring at her from behind a barbered wire fence". Rose's compassion is awakened and all through the winter, despite increasing food shortage, she secretly brings food from home to them saving her own food for them which makes her grow thinner and paler for every day. 
The children were always waiting for her by the fence. When they took the food, careful not to touch the electric wires, their thin hands trembled.

Rose Blanche learned their names, told them hers and told them all about her school.

The children said little in reply. Huddled together, they stared through the fence into the distance.

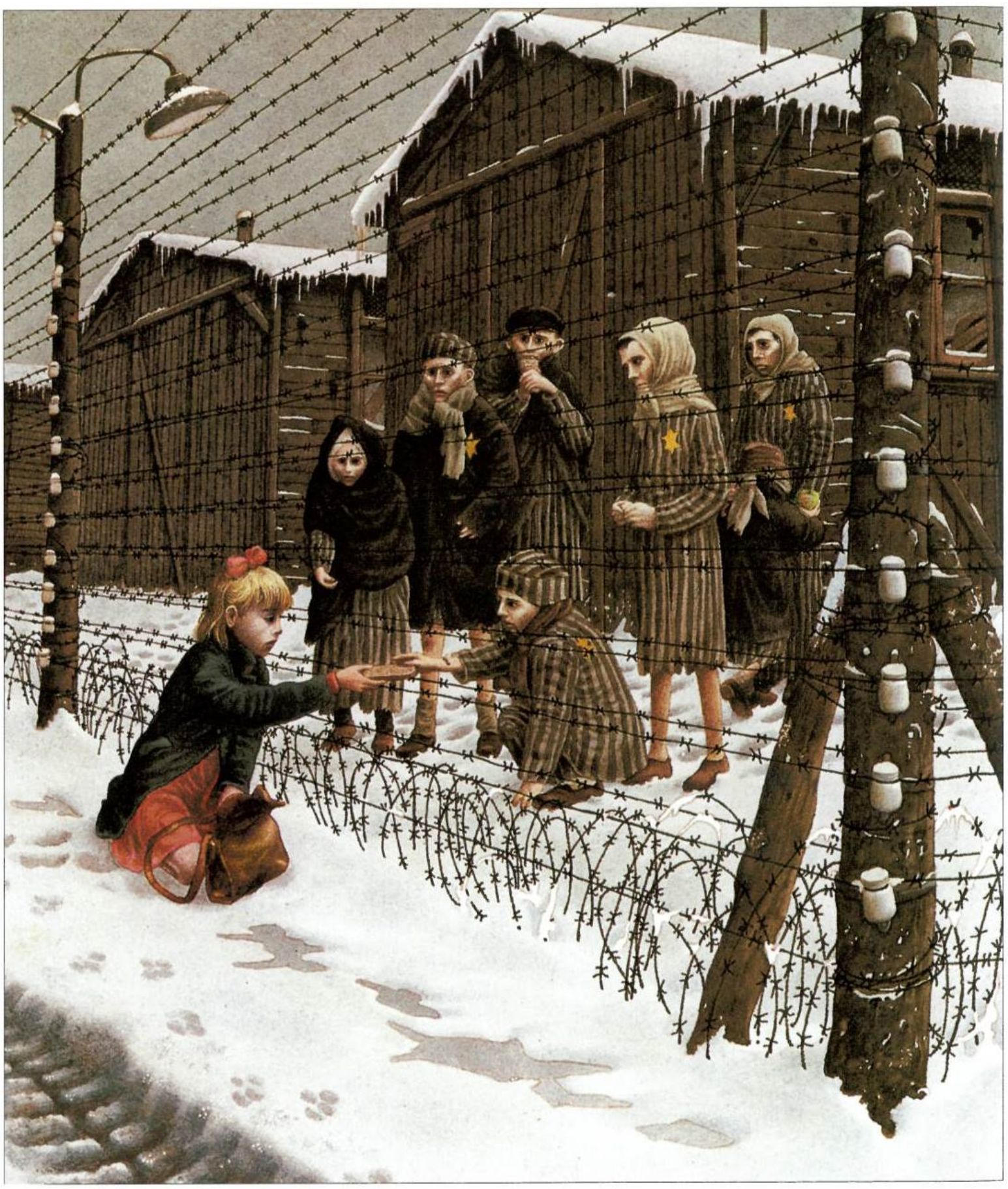

Figure 6: Rose Blanche by Ian McEwan and Robert Innocenti. 
As the snow is melting, exhausted and wounded soldiers start pouring back into the village, Fear makes the whole town decide to leave, but nobody can find Rose who is heading through the forest to the children. The camp has been torn down, but fearful soldiers move through the fog, and then a shot rings out. The story changes scene, and we are back in the town where allied soldiers have arrived. The final double spread shows that spring has triumphed where the concentration camp used to be, but "Rose Blanche's mother never found her little girl". Rose Blanche is a story of great sadness, but with some hope of a new beginning in end through the spring covering up the traces of the concentration camp.

The illustrations are meticulously realistic showing authentic details from Nazi Germany. There are the red-brick buildings and the red flags with swastikas on; there are the lorries with blind windows and the tanks with soldiers in grey uniforms, and the concentration camp with the prisoners in striped prisoner clothes. Authentic graffiti in German on the walls ironically states "Den Krieg gewinnen wir und kein anderen!" The illustrations provide "layer upon layer of historically authentic material" (O’Sullivan: 2005:153).

An example of intertextuality is found on the $4^{\text {th }}$ doublespread which shows the little Jewish boy holding his hands above his head (figure 7). This illustration alludes to the SS Officer Jurgen Stroop's famous photograph of the boy in the Warsaw Ghetto. 
The mayor was immensely pleased with himself. He dragged the boy by the scruff of the neck back to the lorry.

One of the soldiers was furious and shouted at the boy who burst into tears.

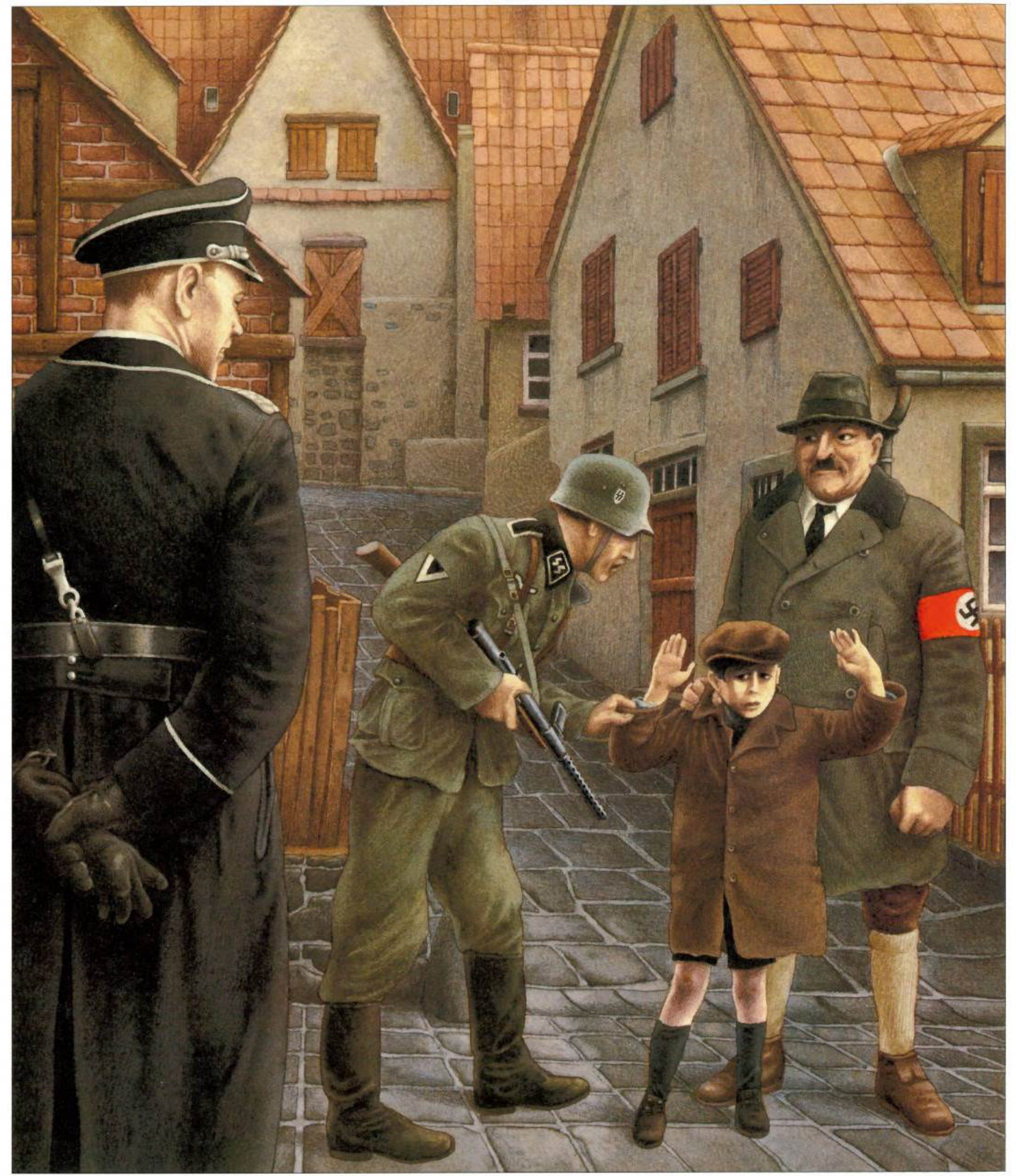

Figure 7: Rose Blanche by Ian McEwan and Robert Innocenti. 
The front cover shows Rose looking out through a window at what is happening in the street. In the window, are reflections of wounded and exhausted soldiers pouring back into the town, and as thus, the front cover functions as a kind of foreshadowing. Apart from the first illustration of Rose with her mother and townspeople, Rose is pictured in an observing position such as looking through windows or she is on one of the sides of the illustrations witnessing what is happening. The colours are kept in darkish tones except for Rose's red hair bow and the red flags with swastikas. On the last picture of Rose (figure 8), the red bow has disappeared and Rose wears a white dress laying a flower on the barbered wire. She is reminiscent of a Christ figure (O’Sullivan: 2005:153) or appears as a martyr (Stan, 2004: 27).

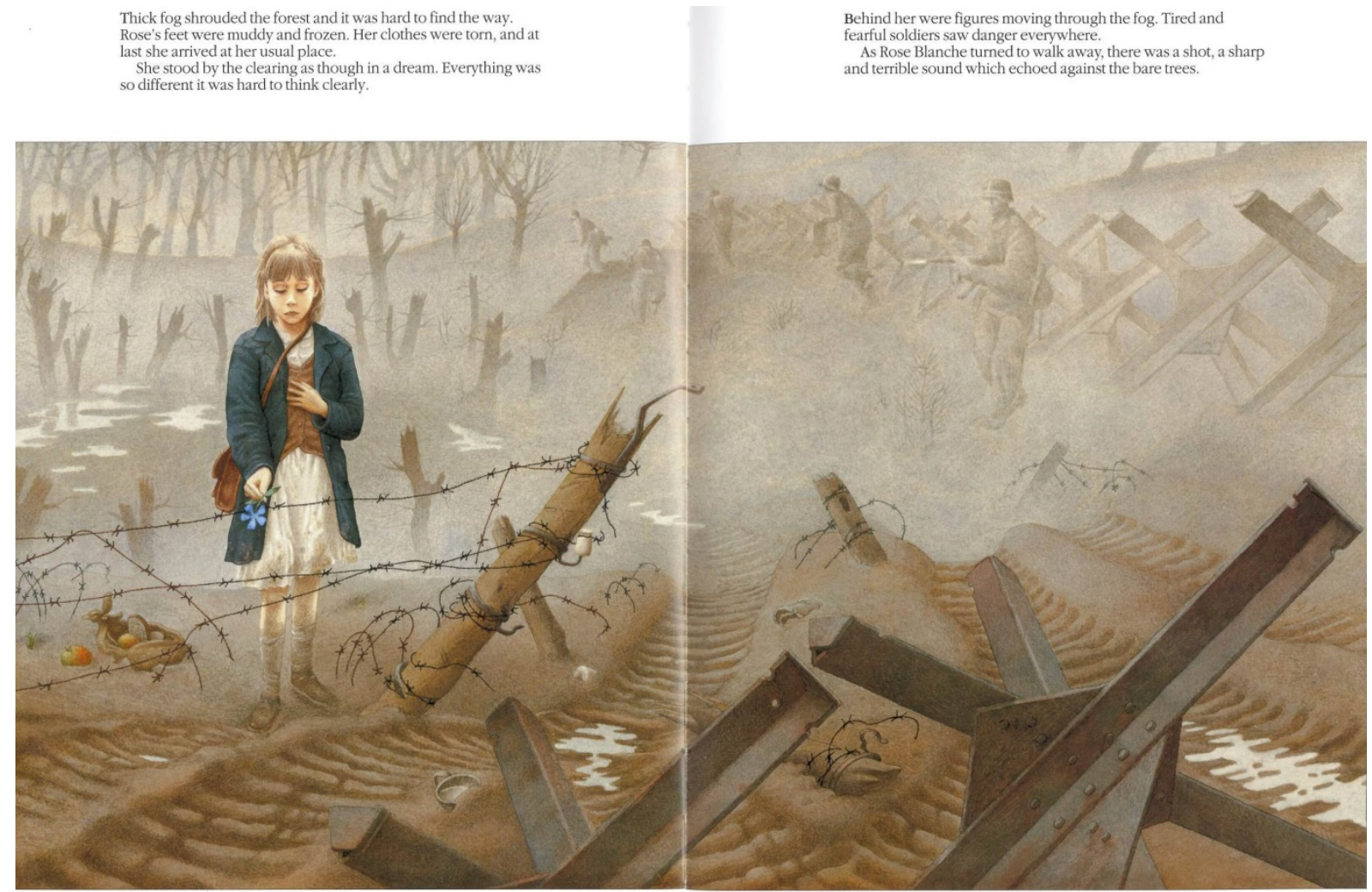

Figure 8: Rose Blanche by Ian McEwan and Robert Innocenti.

The very last page has a close-up of barbered wire with a flower which brings across an important message of the book: compassion. The last double-spread of the spring-clad clearing in the forest (figure 9) is a fabulous celebration of spring with a sparkle of flowers and radiant colours. It also reinforces the cyclic aspects of the book and the symbolic significance of the seasons. Spring offers a new beginning and a second chance to be good. 


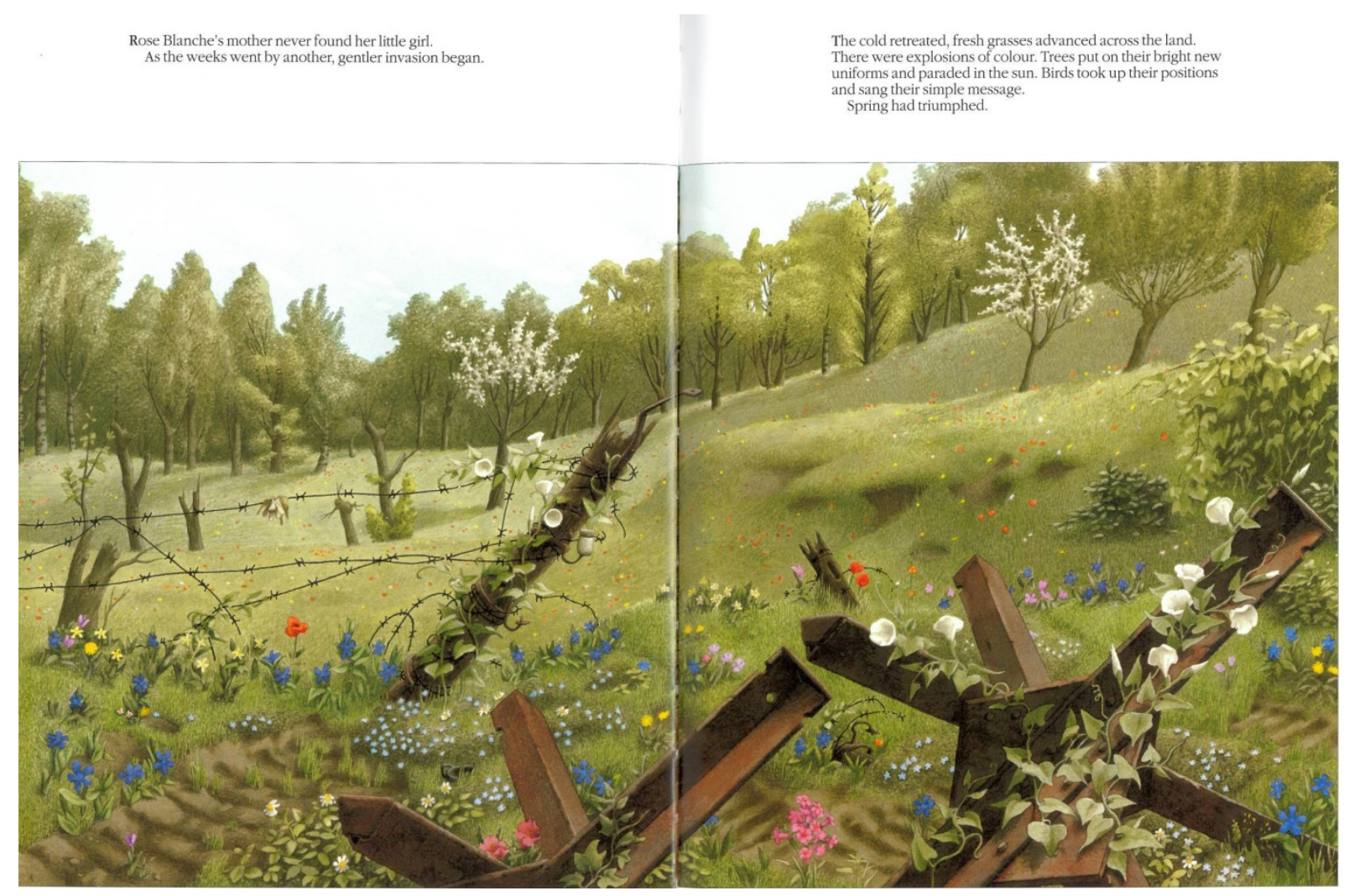

Figure 9: Rose Blanche by Ian McEwan and Robert Innocenti.

In school, picture books are ideal for cross-curricular work with arts and an aesthetic appreciation of the text should be encouraged at all levels. The learners can be asked to reflect on the front and back cover and on the colours used in the pictures. They can be asked why Rose's red bow disappears towards the end as her dress becomes white (figure 8). This is a way to draw attention to symbolism hidden in the pictures. The learners can also be asked to reflect upon what the pictures tell that the verbal text does not tell and vice versa. This can for example be done with the 3rd double spread showing Rose walking her favorite way home from school or with the last double spread of spring triumphing (figure 9).

The level of the verbal text of the story would be suitable for learners in upper primary school and onwards $(12+)$. The story uses everyday language, is told in the past tense, and the sentences are not too complex, as the following extract shows: "One day a lorry broke down. Rose Blanche saw two soldiers trying to repair the engine. Suddenly a little boy leapt from the back of the lorry and ran down the street. A soldier shouted, Stop or I'll shoot. The boy ran straight into the arms of the fat mayor" (4th double spread). This story can be used to practise past tense of both strong and weak verbs. It can also be used to learn new vocabulary through asking pupils to describe what they see in the pictures. They can do this orally in pairs and then write up a paragraph or two about one of the pictures. A brainstorming activity on the smart board beforehand might be useful in helping them focus on new vocabulary. 
Another way to use this Picture book is a cross-curricular project of history and English, as the Second World War is a topic in the $9^{\text {th }}$ grade. As mentioned, the verbal text is relatively straight-forward and would be manageable for most learners. The pictures provide both help in understanding the story and add important authentic details. Furthermore, if doing extensive reading in lower secondary school with war as a theme, this Picture book can be used together with The Boy in the Striped Pyjamas (Boyne, 2006). As it is a story with visual support and a brief text, this book may be a choice for reluctant readers.

Zoo by Anthony Browne

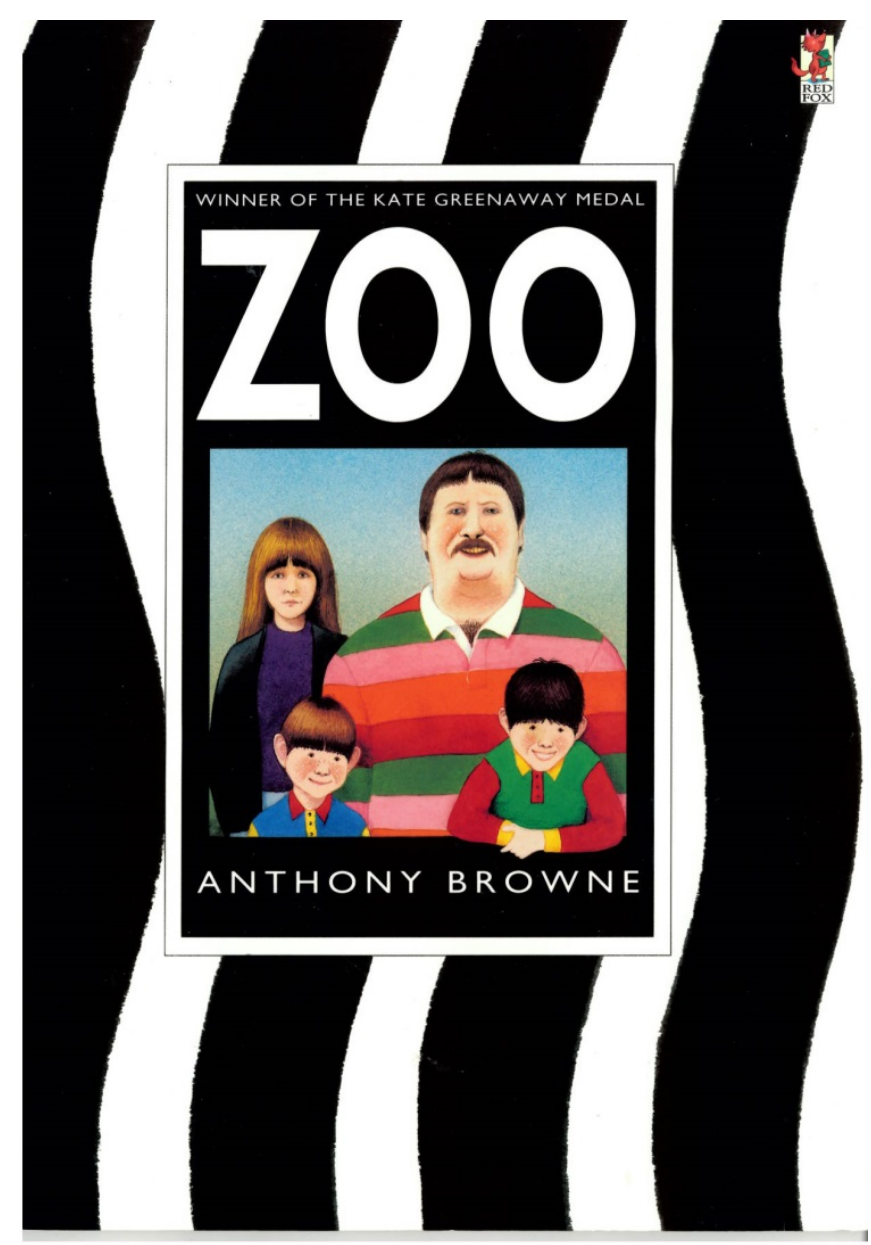

Figure 10: Zoo by Anthony Browne

This book has been chosen as object of study as it addresses dual audiences (Wall, 1991). It is written by Anthony Browne, who is both writer and illustrator, and was appointed Children's Laureate in 2009. His books engage both children and adults. His picture books have 
recurring themes and distinctive leitmotifs such as gorillas, brick walls, rainbows and anthropomorphic tree trunks. Moreover, he borrows abundantly from the surrealist painter René Magritte such as for example in Voices in the Park (1994[1992]) where hats appear as lamp posts as well as symbols of power. See Literature for the English classroom: theory into practice (Birketveit and Williams, 2013) for a thorough discussion of Voices in the Park.

Zoo was awarded the Kate Greenaway Medal in 1992. Zoo tells a story of a family of four's visit to a zoo. The family consists of a mother and a father and two boys. The title Zoo on the front cover is reminiscent of a pair of google eyes underlining the motif of observation pervading the book. In addition to a framed picture of the family and the title, the cover consists of black and white stripes giving associations to zebra stripes. The zebra motif is repeated in the end papers. An interesting detail is that the black and white pages change position at the end. The front endpapers are white (left) and black (right) whereas the back end papers are black (left) and white (right). The colour of the family members' clothes reflects their characters. Thus, the father and the boys are clad in colourful clothes and are outgoing and dominant, whereas the mother wears darkish clothes, and appears serious and worried. Hints of male aggression appear in the verbal text as well when the father "had to have a row with the man in the ticket booth" (2nd double spread). And later "My brother thumped me, so I kicked him and we wrestled for a bit" (6th opening).

In a Picture book, the left hand side is usually the home page, the safe page and the right hand page is considered the adventure page where exciting things happen (Nikolajeva, 2006: 132).. This is not the pattern in this book. Throughout the family's visit to the zoo, the human beings are consistently pictured on the left hand side whereas the animals are on the right. Thus, human beings and animals have separate spaces in the book as in a real zoo. It also allows the reader to make interesting comparisons of the two. When the back end paper turns black where the human space, is this can be seen as a subtle statement about the true nature of human beings.

Although this looks like a modern zoo, the theme of captivity and confinement is portrayed through images of cages, fences, walls and barren trees. The tiger walking along the fence (figure 11) is enclosed by black railings. 


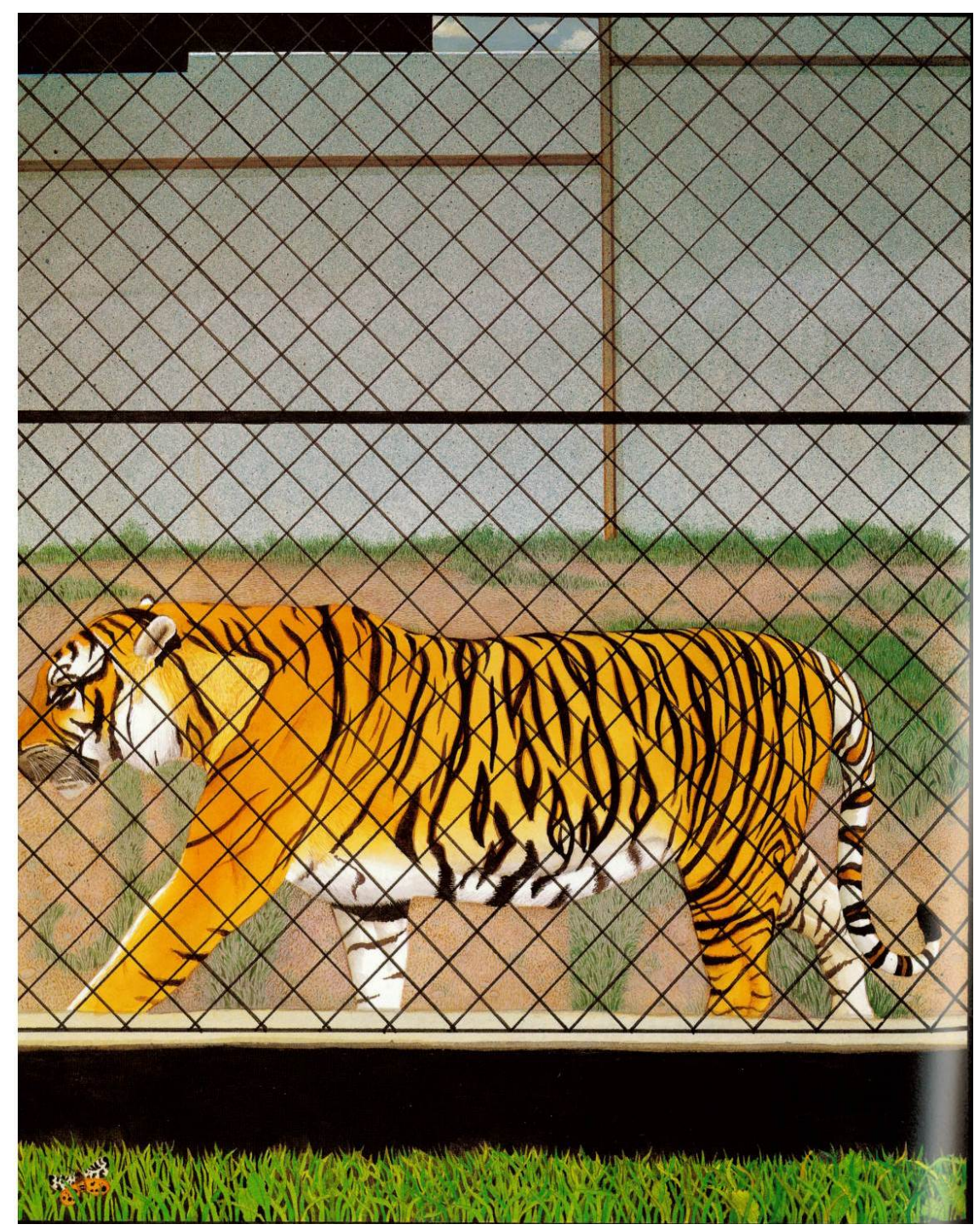

Figure 11: Zoo by Anthony Browne

As the story develops, the human beings increasingly take on animal features, for example where the visitors are banging on the window to make the crouched orangutan move (10th double spread). When they find the gorillas, even the father's language has become animal sounds. The theme of animals suffering in captivity is reinforced both by the orangutan hiding in a corner (figure 13) and by the close-up of the gorilla with sorrowful eyes. The symbolism of the bars painting a white cross over his face cannot be missed (figure 15). 


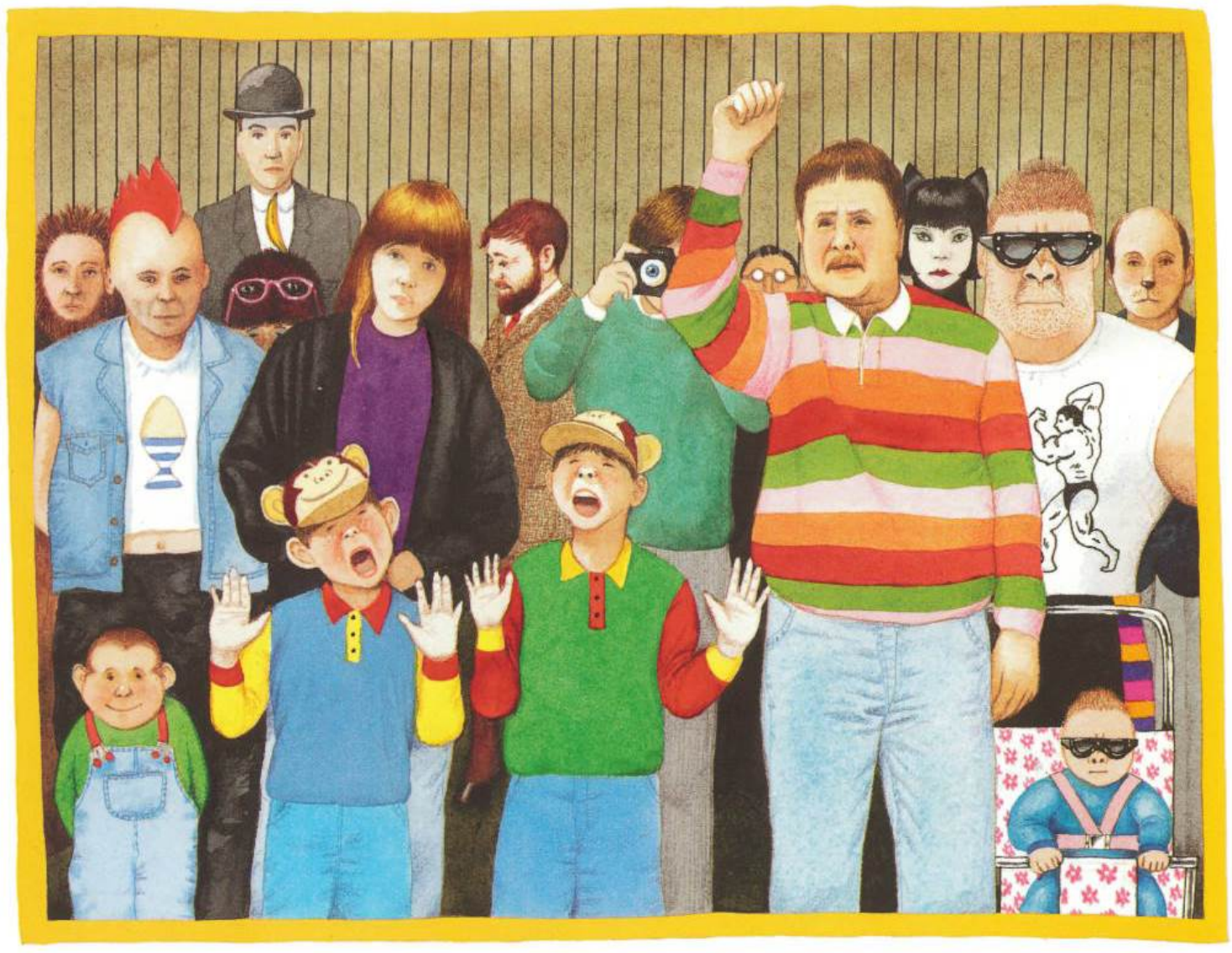

The orang-utan crouched in a corner and didn't move. We tried shouting at it and banging on the glass, but it just ignored us. Miserable thing.

Figure 12: Zoo by Anthony Browne 


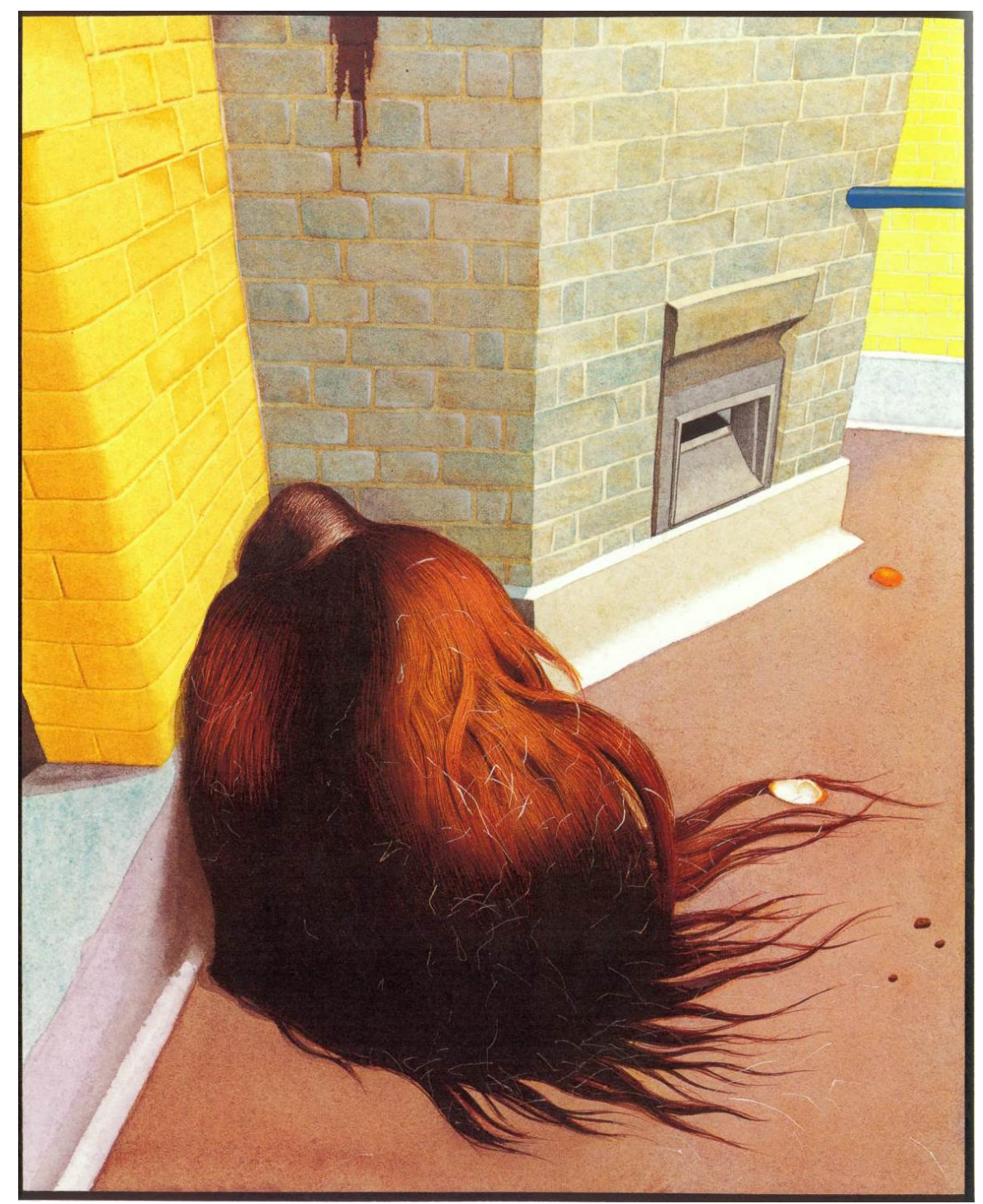

Figure 13: Zoo by Anthony Browne

It is interesting to examine the perspective of the illustrations. With the boys fighting in the background, the 9th double spread shows the mother looking directly at the reader and at the baboons saying "They remind me of someone... I can't think who" (figure 14). In fact, here as well as elsewhere, the point of view or the who sees can be the animals looking back at the humans visiting the zoo. The mother's final comment on their outing is "I don't think the zoo really is for animals... I think it is for people". Although rare, this is an example of how the verbal text and not only pictures can add important meaning to the iconotext. Moreover, it is interesting that this is the only place in the verbal text where a critical comment on animals held in captivity is expressed. According to Styles and Arizipe, all the evidence for an authorial stance critical of zoos comes from the pictures" (2001:263). 


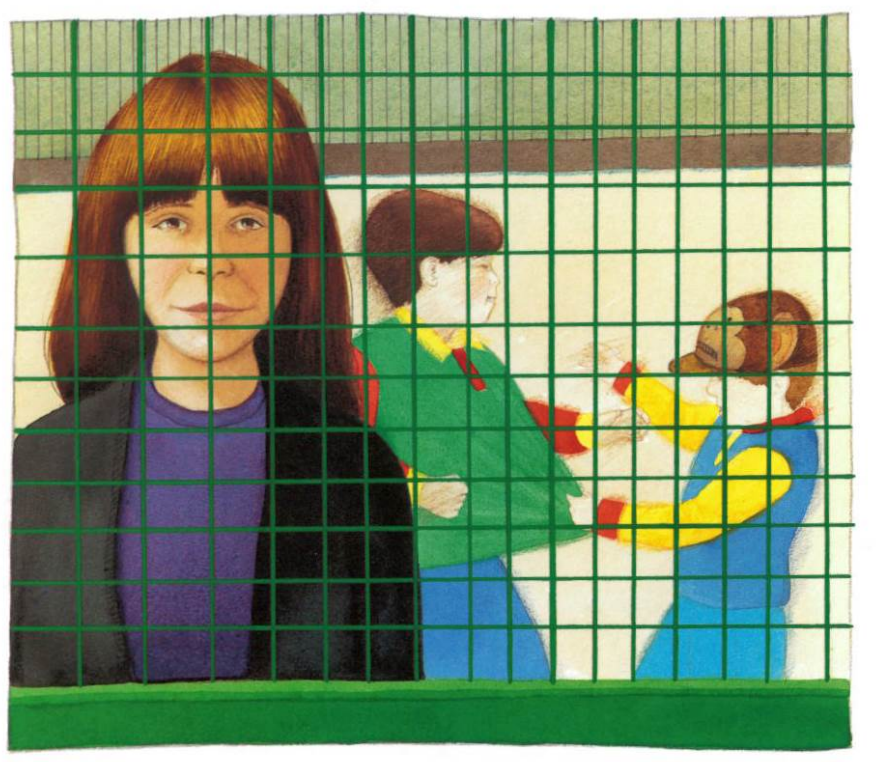

Next we saw the baboons, and they were a bit more interesting. Two of them had a fight. "They remind me of someone," said Mum. "I can't think who."

Figure 14: Zoo by Anthony Browne 

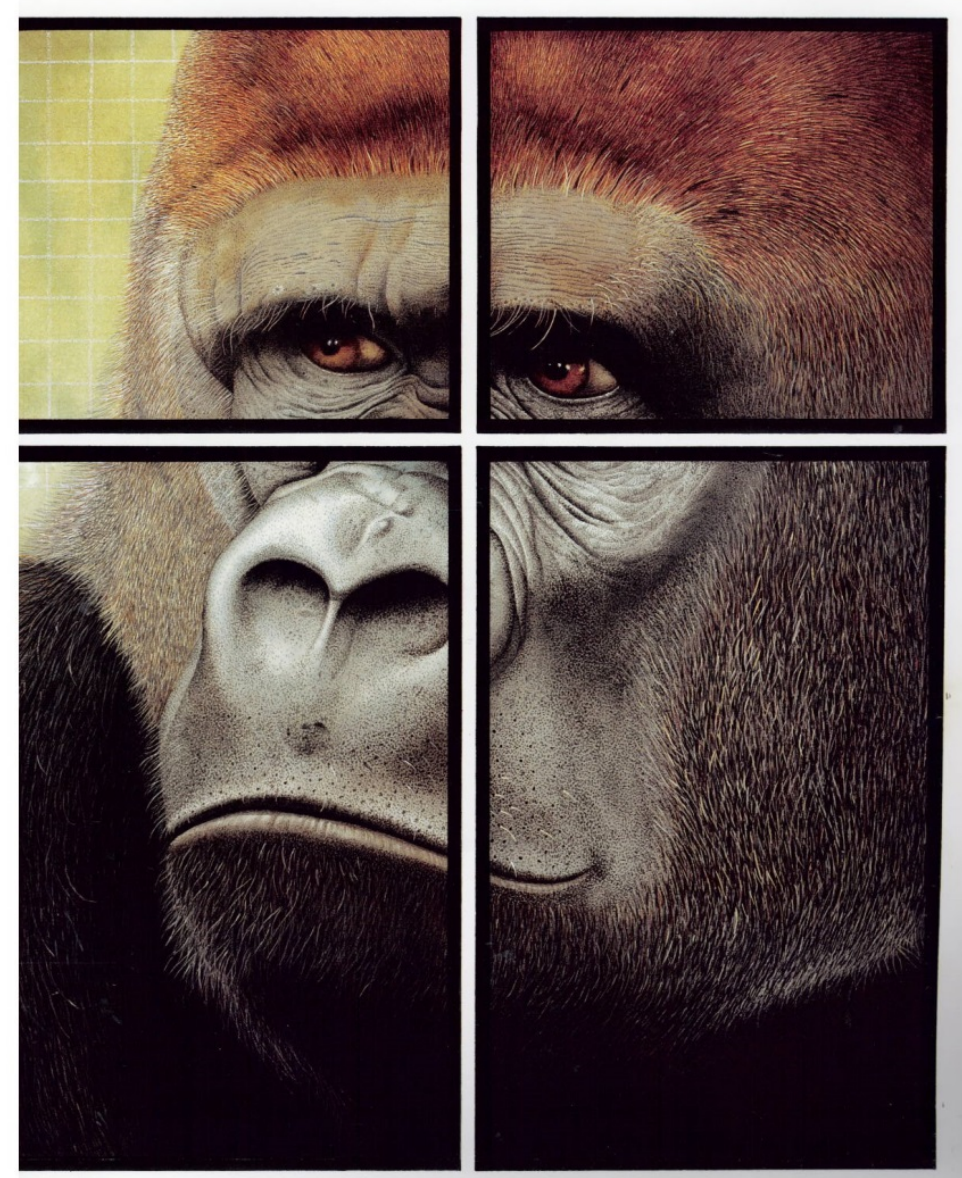

Figure 15: Zoo by Anthony Browne

Browne himself says about the book, «I sometimes use animals to show a side of our nature that we repress. And many children haven't learned to express that side of our nature... I don't think the book is as bleak as people thought it was either. I mean I know it's a harsh view of males. I was only reminding us all that we are animals ourselves and we forget that" (an interview with Browne quoted in Styles and Arizipe,"(2001:265).

Zoo is a sophisticated Picture book for a dual audience. The skilful interaction of pictures and text, makes it an excellent choice for developing visual literacy both with children and adults. The illustrations have small changes pertaining to the message of the story, for example people in the queues growing animal ears or feet or having beaks for noses. Also the way the animals' enclosures are illustrated calls for interesting interpretations. The significance of the colours used is another feature to draw the readers' attention to. Furthermore, a discussion of the cover, the endpapers and the significance of the title page with a picture of a hamster in a cage can be enlightening. 
In addition to developing visual literacy, the book can be used in many ways in EFL. The language is not very difficult as the story is told in the past tense from the 1st person perspective of one of the boys and with quite a lot of dialogue. The language seems manageable for 4th graders onwards $(10+)$, and there is a lot of visual support in the illustrations. On a lower level $(10+)$, it can be used to learn vocabulary related to animals in a zoo and their actions. On a higher level (12+), the book can inspire discussions about animal rights as well as family roles.

The book can be used to inspire a cross curricular project of English and arts. After reading and discussing Zoo, the learners (aged 10+) can be asked to make their own picture book in English. They will have to make important choices concerning format, covers, colours, fonts, what endpapers to use, what the title page should look like, what kind of illustrations to use and where to place them, what verbal text should accompany the pictures and where should it be placed on the double spread. Through such a project, both aesthetic skills and English skills will be challenged.

\section{Conclusion}

Reading is one of the basic skills emphasised in LK06, and both intensive (reading for detail) as well as extensive reading skills need to be developed. In addition, learners' ability to read images needs to be taught and practised. As my discussion has attempted to show, picture books are exciting and engaging texts for developing visual as well as verbal literacy.

In my discussion of the three Picture book chosen, the aim is to show how the interaction of pictures and verbal texts works together to bring across messages. In The Stinky Cheese Man children's well-known tales are subverted and the iconotext plays with Picture book conventions making them part of the narrative and tears apart the illusion of a book. In Rose Blanche, the detailed and hyper-realistic illustrations of a German small town during World War II provide an essential part of the narrative at the same time as they reveal the characters' emotions. Zoo addressing both children and adult readers, puts up to scrutiny both human and animal behavior in a confined space. The alert reader is left with the question of who is looking at who in a zoo. Perhaps human behavior is just as interesting as animal behavior. The serious message and the power of the story lie in the subtle details of the illustrations juxtaposed with factual and neutral verbal text. As my discussion has attempted to show, picture books can be very complex, often playful and bring across important messages through the skilful interaction of pictures and words. Readers at different levels find them appealing and accessible, and they are indeed a treasure trove for EFL waiting to be discovered.

\section{References}

Al-Homoud, F. \& Schmitt, N. (2009). Extensive reading in a challenging environment: A comparison of extensive and intensive reading approaches in Saudi Arabia. Language Teaching Research, 13, 383-401.

Arizipe, E. \& Styles, M. (2003). Children Reading Pictures. London: Routledge. 
Bader, B. (1976). American Picture Books from Noah's Ark to the Beast Within. New York: Macmillan.

Barthes, R. (1977). The rhetoric of the image. In R. Barthes, \& S. Heath (eds.), Image, music, text. London: Fontana Press.

Beckett, S.L. (2002). Recycling Red Riding Hood. New York: Routledge.

Bell, T. (2001). Extensive reading: speed and comprehension. The Reading Matrix, 1.

Birketveit, A. (2013). Picture books. In A. Birketveit, \& G. Williams (eds.), Literature for the English Classroom; Theory into Practice (pp. 17-54). Bergen: Fagbokforlaget.

Birketveit, A. and Williams, G. (2013). Literature for the English classroom; Theory into Practice. Bergen: Fagbokforlaget.

Birketveit, A. \& Rimmereide, H.E. (2013). Using authentic picture books and illustrated books to improve L 2 writing among 11-year-olds. The Language Learning Journal.Accessed 8 Nov 2013 from http://dx.doi.org/10.1080/09571736.2013.833280

Bland, J. \& Lütge, C. (2013). Children's Literature in Second Language Education. London, New York: Bloomsbury.Boyne, J. (2006). The Boy in the Striped Pyjamas. Ireland: David Fickling Books Ltd.

Browne, A. [1992](1994). Zoo. London: Red Fox..

Cho, K.S. \& Krashen, S. (1994). Acquisition of vocabulary from the Sweet Valley High Kids series: Adult ESL acquisition. Journal of Reading, 37, 662-667.

Elley, W. (1991). Acquiring literacy in a second language: The effect of book-based programmes. Language Learning, 41, 375-411.

Gallaz, C. (1985). Rose Blanche. Translated by M.Coventry \& R.Graglia. Mankato, MN: Creative Education.

Genette, G. (1997). Paratexts. The Thresholds of Interpretations. Cambridge:Cambridge University Press.

Hafiz, F. \& Tudor, I. (1989). Extensive reading and the development of language skills. English Language Teaching Journal, 43, 4-13.

Hitosugi, C.I. \& Day, R.R. (2004). Extensive reading in Japanese. Reading in a Foreign Language, 16, 20-39.

Hutchins, P. (1968). Rosie's Walk. New York: Alladin Paperbacks.

Iser, W. (1978). The Act of Reading. A Theory of Aesthetic Response. Baltimore: Johns Hopkins University Press.

Kress, G.R. and van Leeuwen, T. (1996) Reading Images. London: Routledge.

Loreplanverket for Kunnskapsløftet. (2006). English subject curriculum. Revised 21 June 2013. Oslo: Utdanningsdirektoratet. Accessed 12.05.2014from http://www.udir.no/k106/ENG1-03/Hele/?lplang=eng

McEwan, I. [1985](2004). Rose Blanche. London: Red Fox.

Meltzer, E. B. (2013). Approaching literary and language competence: Picture books and graphic novels in the EFL classrooom. In J. Bland \& C. Lütge (eds.), Children's Literature in Second Language Education. London, New York: Bloomsbury.

Moss, G. (2003). Putting the text back into practice. In C. Jewitt \& G. Kress (eds.) Multimodal literacy (pp.73-87). New York: Peter Lang.

Mourao, S. (2013). Picture book: Object of discovery. In J. Bland \& C. Lütge (eds.), Children's Literature in Second Language Education. London, New York: Bloomsbury.

Nikolajeva, M. and Scott, C. (2006). How Picture books Work. New York: Routledge.

Nikolajeva, M. (2006). Word and Picture. In C.Butler (ed.) Teaching Children's Fiction (pp 
106-151). New York: Palgrave Macmillan.

O’Sullivan, E. (2005). Rose Blanche, Rosa Weiss, Roasa Blanca: A comparative view of a controversial picture book. The Lion and the Unicorn 29 (2), 157-170.

Pantaleo, S. (2006). The Stinky Cheese Man: A tossed salad of parodic re-versions. In Children's Literature in Education, 38, 277-295.

Penne, S. (2010). Litteratur og film I klasserommet. Didaktikk for ungdomstrinnet og videregående skole. Oslo: Universitetsforlaget.

Pilgreen, J. \& Krashen, S. (1993). Sustained silent reading with high school ESL pupils: Impact on reading comprehension, reading frequency, and reading enjoyment. School Library Media Quarterly, 22, 21-23.

Rimmereide, H.E. (2013). Graphic novels in EFL learning. In Birketveit, A. and Williams, G. (eds.) Literature for the English classroom; Theory into Practice. Bergen: Fagbokforlaget.

Robb, T. N. \& Susser, B. (1989). Extensive reading vs. skills building in an EFL context. Reading in a Foreign Language, 5, 239-51.

Schmitt, N. (2010). Researching Vocabulary: A Vocabulary Research Manual. Basingstoke: Palgrave Macmillan.

Scieszka, J. \& Smith, L. (1993). The Stinky Cheese Man and Other Fairly Stupid Tales. London: Puffin.

Sipe, L. \& McGuire, C.E. (2006). Picture book Endpapers: Resources for Literary and Aesthetic Interpretation. In Children's Literature in Education 37(4), 291-304.

Stan, S. (2004). Rose Blanche in Translation. Children's Literature in Education, 35(1), 21 33.

Styles, M. and Arizipe, E. (2001) A gorilla with "Grandpa's eyes": How children interpret visual texts - A case study of Anthony Browne's Zoo. Children's Literature in Education, 32(4), 262-281.

Wall. B. (1991). The Narrator's Voice. The Dilemma of Children's Fiction. Basingstoke: Macmillan. 